\title{
Leszek Gęsiak
}

ORCID: https://orcid.org/0000-0003-2816-7542

Jesuit University Ignatianum in Krakow, Poland

\section{America Media: \\ A Religious Media Case on the U.S. Market}

\begin{abstract}
In the whole world, independently of the country, we observe the process of media concentration. More and more huge consortia and media groups are being created. This often causes small, individual, autonomous titles, portals, radio or television stations to be displaced. This process of media evolution also affects religious media. An example of this could be the America Media consortium, with headquarters in New York. It belongs to the Jesuits, the Catholic order, and it is administered and developed by the same order. This descriptive study presents the process of the evolutionary transformation of America weekly magazine, which is over 100 -years old, into a multi-dimensional media platform with a global scope. The new and modern media consortium is developing the wonderful history of the printed Catholic magazine. It is present in all the most important media areas: magazine, radio, television and internet. According to global trends, a key factor in America Media is the social media through which they bring a large number of readers, listeners and viewers. Most popular are radio podcasts and TV interviews available via Facebook and the YouTube channel. This evolutionary process is presented in the context of variety of Catholic American media. The specific elements of the mission of the Catholic consortium, the adopted development strategy, possible perspectives of this media complex in the near future, and existing difficulties are also discussed in this paper. The study was largely based on a visit made to America Media headquarters in October 2018.
\end{abstract}

\section{Keywords}

America, Catholic press, Church, consortium, Facebook, Internet, Jesuits, magazine, mass-media, podcasts, social media, USA, YouTube. 


\section{Introduction: Catholic media in the face of technological changes in the modern media}

The process of media evolution in the world is ongoing. The latest technological achievements, the development of social media, the dynamic enhancement of forms of information spread, and especially the immediacy of the message, make the image of institutions dealing with both information and journalism, continually open to new forms of expression. The constant introduction of innovations and adaptation to the rapidly changing needs of the media market demand that many entities that deal with information and social media respond to these new challenges.

Of course, this process also applies to religious media, independent of the location in the world. The best example of this is the reform of the media system of the Holy See, which was started several years ago by Pope Francis. The purpose of the current process of changes in the Vatican media is not only to reduce the very high costs of maintaining this type of institution. This process also aims to adapt the Vatican media to the technological requirements of the modern world and to the excessive expectations of the potential audience. $^{1}$

The same applies to other media entities that identify themselves with a particular religion or denomination, or with a specific philosophical outlook. In the era of electronic media, it is obvious that a printed weekly or even a well-written text on a website is not enough for the proper transmission of information and communication with a media audience. World trends tend to indicate the multidimensionality of each medium, where the written word, photo, sound, film and many other additional effects will be integrated and subordinated to one common program and technological vision.

The trends in the organization of contemporary media described above have their specific justification. The actions undertaken are largely due to market conditions and ever-increasing competition. This means that it is necessary for broadcasters and producers to constantly "fight” for readers, viewers or listeners. In a very specific way, this applies to religious media. Very often the marketing and promotional element should be subordinated there to the promotion of a particular system of values and religious beliefs. In the case of Catholic

${ }^{1}$ Cf. L. Gęsiak, Reform of the Vatican media, a difficult search for a new path, "The Person and the Challenges" 7 (2017) 2, pp. 5-22. 
media, they are obviously linked with their missionary dimension, which is the spreading of faith. ${ }^{2}$

An interesting example of the evolution occurring in the media is the America Media consortium. It belongs to the Catholic religious order of the Jesuits ${ }^{3}$ and it is administered and developed by the same order. The headquarters of America Media is located in New York. ${ }^{4}$ The main sources of information for this study, which is descriptive, are interviews made both with people managing the America Media consortium as well as with those responsible for particular departments: Maurice Timothy Reidy - Deputy Editor in Chief, Edward Schmidt SJ - Senior Editor, Zac Davies - Associate Editor for Digital Strategy, Eloise Blondiau - Producer, Olga Segura - Associate Editor, Leopold Stuebner SJ - Associate Editor, Ashley McKinless - Associate Editor, America's podcast for young Catholics, Emma Winters - The Joseph A. O'Hare, S.J. Postgraduate Media Fellowship Program of America Media. ${ }^{5}$ None of these interviews were published, however, the entire documentation is in the author's private archive.

\section{America Media case: the history of the consortium}

The history of the America Media consortium is long and its beginnings are related to its flagship product, America Magazine. It was founded by the Jesuits

${ }^{2}$ Paul VI, Inter Mirifica. Decree on the Media of Social Communication, point 3, http://www. vatican.va/archive/hist_councils/ii_vatican_council/documents/vat-ii_decree_19631204_intermirifica_en.html (17.01.2020).

${ }^{3}$ Jesuit (Society of Jesus) is a religious congregation of the Catholic Church founded in 1540 by Saint Ignatius of Loyola.

${ }^{4}$ On visiting the headquarters of the consortium in the office building on 1212 Avenue of the Americas, in the centre of Manhattan, one gets the irresistible impression that one is dealing with one of the leaders on the media market. The confirmation of this observation is that other media giants' headquarters are located just nearby. For example, the headquarter of the News Corporation (to which 21st Century Fox belongs) is located literally on the other side of the same street, whilst NBC NEWS is located in the nearby Rockefeller Centre. But there is something special. "America Media hit Marvel [Architects, a New York design firm], with a requirement for its new offices in Midtown Manhattan that the architects had never encountered working with previous office clients. It wanted a chapel”; conf. J. Margolies, Media Headquarters With Room to Report, Videotape and Worship, “The New York Times" (New York Edition), 18 of July 2018, p. B6.

${ }^{5}$ Research and interviews were conducted at the headquarters of the consortium in New York during the research visit in October 2018. 
and has been published since April 17, 1909. It is one of the oldest catholic magazines published in the USA. Its initiator and first editor-in-chief was Fr. John J. Wynne S.J. (1859-1946). ${ }^{6}$ The idea of creating a new magazine was born when he served for several years as the editor-in-chief of the American version of the Messenger of the Sacred Heart. ${ }^{7}$ This magazine contained only religious content.

Fr. Wynne, understanding the needs of contemporary Catholics, decided in 1902 to diversify it and he created two independent publications. The first of them remained at the title of the Messenger of the Sacred Heart and retained the character of the strictly religious script. It became the official magazine of ecclesiastical organization Apostleship of Prayer. The second publication was Messenger, a Catholic magazine with a broader thematic scope. ${ }^{8}$ This publication, allowing a multi-faceted look at religious issues, became, seven years later, the foundation of the America weekly. ${ }^{9}$

This magazine, published by the Jesuits for over a century, has gained a lot of readers, supporters, and benefactors. It became an important opinion-forming entity, mainly in the Catholic intellectual sphere. Members of the Jesuit order from various provinces in the United States have contributed to this revue for years. From the 1930s, the magazine was involved in the promotion of social and racial justice, acquiring texts written by Catholic authorities. In 1965, with a circulation of 100,000 copies, it became the largest Catholic weekly in the United States. ${ }^{10}$

${ }^{6}$ The beginnings of the magazine America were described by Michael F. Lombardo, see: M. F. Lombardo, Founding Father. John J. Wynne, S.J. and the Inculturation of American Catholicism in the Progressive Era, Leiden-Boston 2017, Brill, pp. 231-294.

Messenger of the Sacred Heart was a worldwide Jesuit publication connected to the devotion of the Sacred Heart of Jesus. It was edited in many countries and languages starting of the second half of 19th century. In some countries it is still being published until now, e.g. in Ireland; see: https://www.messenger.ie (17.01.2020). Fr. Wynne was an editor-in-chief of the English version published in the US.

${ }^{8}$ The Provincial of the Maryland - New York Province Fr. Thomas J. Campbell had the idea of the creation of a publication for the intellectual life of US Catholics in the late nineteenth century. When Fr. Wynne created a new magazine, "he would also use the „Messenger” to fulfil Campbell's dream of founding a Jesuit intellectual review", see: M. F. Lombardo, Founding Father. John J. Wynne, S.J. and the Inculturation of American Catholicism in the Progressive Era, Leiden-Boston 2017, Brill, p. 234.

${ }^{9}$ Cf. T. H. Stahel, America, in: M. Glazier, T. J. Shelley (eds.), The Encyclopedia of American Catholic History, Collegeville, Minnesota 1997, The Liturgical Press, p. 21.

${ }^{10}$ Cf. M. McLoughlin, Catholic Magazines and Periodicals, in: M. Glazier, T. J. Shelley (eds.), The Encyclopedia of American Catholic History, Collegeville, Minnesota 1997, The Liturgical Press, s. 275. 
For many years, it supported anti-communist ideas, sympathizing with, among others, Catholics who supported General Franco during the civil war in Spain.

The magazine was also an important transmitter of the thoughts of the Second Vatican Council. It was reporting and commenting on its pages during the whole course of the Council. The weekly was not afraid of polemics and discussions related to the Church. One of the cases was, among others, discussion of the encyclical Humanae Vitae after its promulgation by Pope Paul VI. After the Council, America was promoting its reforms. At the same time the magazine tried to balance between extreme liberal and conservative opinions in the reform within the Church. Editors also wanted to fulfill the role of being a bridge in the process of dialogue within the Church. ${ }^{11}$ The weekly also promoted interfaith dialogue and enjoyed a high international recognition of ecumenical environments. ${ }^{12}$

Thanks to the acquired funds, the magazine could dynamically develop and consolidate its brand in a very demanding and competitive American market. With time, alongside the magazine, an important Catholic publishing house was created: America Press. However, new technologies of information transfer, especially the Internet and social media, forced further changes and necessary development in order to maintain America's place on the American media market. The result was that the editors began to create radio and television programs.

In 2015, America Press publishing house, which was the publisher of America magazine, was transformed into the America Media consortium, which now coordinates both the publication of the magazine, as well as the related radio, television and internet production. These activities caused a drop in sales of the number of printed copies of the magazine. But at the same time America Media has recorded a significant increase in readers on websites and social media. From January 2017, a printed magazine appears biweekly with the name America: The Jesuit Review of Faith and Culture. ${ }^{13}$

${ }^{11}$ Cf. T. H. Stahel, America, in: M. Glazier, T. J. Shelley (eds.), The Encyclopedia of American Catholic History, Collegeville, Minnesota 1997, The Liturgical Press, s. 22.

${ }^{12}$ Cf. M. McLoughlin, Catholic Magazines and Periodicals, in: M. Glazier, T. J. Shelley (eds.), The Encyclopedia of American Catholic History, Collegeville, Minnesota 1997, The Liturgical Press, 275.

${ }^{13}$ Cf. About America Media, https://www.americamagazine.org/about-america-media (17.01.2020). 


\section{Towards social media}

Today, the readers of America magazine are in part permanent subscribers, associated with the magazine for many years, often for more than a decade. Most of the regular readers of the printed version are older people who are retired, largely over 70 years of age. This, of course, means that their number will shrink systematically. But this is a constant trend in the US market. According to data published in July 2019 by Pew Research Center, the estimated total U.S. daily newspaper circulation (print and digital combined) in 2018 was 28.6 million for weekday and 30.8 million for Sunday, down $8 \%$ and $9 \%$, respectively, from the previous year. Weekly market looks even worse: weekday print circulation decreased $12 \%$ and Sunday print circulation decreased $13 \% .{ }^{14}$ In the case of America Magazine, it is their subscription that is still one of the most important sources of financing of the magazine. Important amounts of money are also derived from advertising and large-scale fundraising activities. According to people dealing with the finance of the magazine, the funds apart from the subscription fees are increasingly important to its maintenance.

The aging reader, of course, has forced the editor develop other media platforms. According to the deputy editor-in-chief of the magazine, Maurice Timothy Reidy, the key role in reaching today's audience is primarily podcasts and special radio programs. These so-called „radio shows” are broadcast on various radio stations or via the Internet. This allows Reidy and his colleagues to reach new audiences who have never heard of America Media before. It is mainly about people living outside of New York, who can listen to these types of programs while driving to the city. ${ }^{15}$

A separate section is made up of special video recordings. The editorial team has a well-equipped television studio, allowing them to record conversations and to create high quality television programs. These programs are broadcast with varying frequency, mainly on social media such as Facebook. They are also available on their own channel on YouTube. ${ }^{16}$ All statistics are precisely analyzed

${ }^{14}$ Cf. Pew Research Center, Newspapers Facts Sheet, https://www.journalism.org/fact-sheet/ newspapers (17.01.2020).

${ }^{15}$ The interview with Maurice Timothy Reidy and other interviews mentioned in this paper were not published; all interviews and other documentation are in the author's private archive.

${ }^{16}$ Cf. America Media, a Jesuit Ministry, YouTube Channel, https://www.youtube.com/ channel/UCKrLOIYtxTfkBy5ho3FSaA (17.01.2020). 
by the editorial staff. Among all websites administered by America Media, it is the YouTube channel that attracts the attention of Internet users most often.

Among the visual materials, of special interest are the interviews conducted by Fr. James Martin S.J., a Catholic writer and publicist. ${ }^{17}$ Certainly, he is one of the most recognizable media people in the American Church. These talks concern various current topics related to the Church. He invites many people for conversation: famous Americans, church authorities, people who have an important position or social functions. They do not hide behind the fact that they are practicing Catholics. Thus, there are, in these programs, people well known in public life, whose opinions are taken into account by American society. He also proposes daily reflection and introduction to personal prayer. ${ }^{18}$

\section{Catholic press market and America}

According to the research made by the editorial, the biweekly America (the initial element of the consortium) reaches mainly readers in middle and older age, in both printed and electronic versions. The current circulation is 40,000 copies. It is a magazine that deals with matters of faith and culture, which are presented in an easy but profound way. The information provided is not intended to be of a scientific nature; it is to be presented to the audience in an accessible and comprehensible way. The Jesuits who work in the editorial office, with their theological training, are the guarantee that the prepared materials, positions and comments are presented in accordance with the teaching of the Church. The combination of these few elements means that the magazine, although touching difficult problems, is understandable for the readers.

It is worth noting that America has its specific place in the media landscape of Catholic magazines in English, which are many in the U.S. Some, for years present on the market, have developed a very good brand in the media space. An example is the British weekly The Tablet, founded in 1840 . Being present on the American market, it discusses topics in the field of religion, politics, social issues, literature and art. It does it from the Catholic perspective and in the ecumenical dimension. It is fully inspired by the teaching of the Second

\footnotetext{
${ }^{17}$ Cf. America, the Jesuit Review, Voices, James Martin, S.J. Editor at Large, https://www. americamagazine.org/voices/james-martin-sj (17.01.2020).

${ }^{18}$ J. Martin, The Examen with Fr. James Martin S.J., https://examen.libsyn.com (17.01.2020).
} 
Vatican Council. ${ }^{19}$ However, its circulation is much smaller than America. ${ }^{20}$ It is considered a traditional and conservative magazine.

An important place in the panorama of American Catholic magazines is occupied by the bi-weekly National Catholic Reporter. It was founded in 1964, during the Second Vatican Council. The main goal of this publication was to bring to the readers the most important conciliar thoughts. With time, however, the magazine began to provide for Catholics the current information on the life of the Church. It did it in the same style as the largest news agencies in the world, with regard to political and social information. However, this magazine is independent of Churches authorities. The consequence of this is that sometimes it manifests itself in a critical relation to the activities of the hierarchy. It is considered to be progressive.

Another significant inter-faith and interreligious publication is the monthly First Things. ${ }^{21}$ It was founded in 1990. It deals with topics from the perspective of various Christian denominations and religions in the fields of theology, liturgy, history of the Church, history of religion, culture, education, society and politics. Catholic issues are analyzed there from a traditional perspective. From a similar perspective, daily events are documented by the National Catholic Register associated with the EWTN media consortium. ${ }^{22}$

\section{The specificity of the Jesuit biweekly}

According to the editors of the America Media consortium, in this wide panorama of Catholic magazines, the biweekly America is located among various political and ecclesiastical tendencies, with a certain center-left inclination. However, the publishing line has evolved over the years. The changes often took place when a new editor-in-chief was named. The priorities and main forms of journalism have changed. Initially the magazine wrote mainly about

\footnotetext{
${ }^{19}$ Cf. The Tablet, About us, https://www.thetablet.co.uk/about (17.01.2020).

${ }^{20}$ According to data from 2017, The Tablet's circulation amounted to 18772 copies; conf. Wikipedia, The Tablet, https://en.wikipedia.org/wiki/The_Tablet (17.01.2020).

${ }^{21}$ Cf. First Things, https://www.firstthings.com (17.01.2020).

${ }^{22}$ EWTN - Eternal Word Television Network - it is an American Catholic television station founded by Clarisse sister, Mother Angelika OCPA (Poor Clares of Perpetual Adoration). Currently EWTN broadcasts programs in English, German, Spanish, Polish, Hungarian, Swedish and Ukrainian; conf. http://www.ewtn.com (17.01.2020).
} 
the events within the Church. Later on, the main focus was on the issues of the social doctrine of the Church. There were periods when the most editorial space was devoted to political issues, mainly about the Middle East. Current editor-in-chief, Fr. Matt Malone S.J. returned again to focus on everyday news. At the same time the fact that the manner of transmission of news is changing, leads to fact that the printed edition gradually loses importance in favor of the texts published online.

The main permanent sections of the actual online America are: Politics and Society (with the subsections: News, Editorials, Dispatches, US Politics, Civil Rights, Immigration and Environment), Faith (with the subsections: Pope Francis, Faith in Focus, Faith in Reason, Spirituality, Theology, US Church, Scripture, The Word, The Good Word), Arts and Culture (with the subsections: Books, Film, Television, Theater, Poetry, Art, Ideas, Catholic Book Club), Voices, Journeys and Magazine. ${ }^{23}$

In this analysis it is worth noting the very special name which is the title of the magazine: America. It must be remembered that this word is not a synonym of the United States. Although most of the discussed issues are certainly related primarily to North America, especially the United States and Canada, nevertheless, the thematic scope concerns both American continents. Among the authors who regularly write their texts for this magazine there are, for example, several Canadians, but a lot of attention is also paid to Latin America, mainly to countries such as Mexico, Cuba, the Dominican Republic and Puerto Rico. For this reason, there is a lot of space devoted to the Spanishspeaking community of the Church in the USA. So the word "America” in the title does not only refer to the United States. In the magazine there are often texts describing the situation in various local churches in the world, and the authors writing for the biweekly live in different countries (e.g. in Mexico or South Africa).

The readership of America includes U.S. residents as well as representatives of countries such as Great Britain, Australia, Ireland and many others. Analysis of the visits to the website gives a good picture both of the number of readers of the magazine and the places they come from. Notable numbers of readers in places outside the U.S. include Australia, Italy, the United Kingdom and the Republic of Ireland.

${ }^{23}$ Cf. America. The Jesuit Review, https://www.americamagazine.org (17.01.2020). 


\section{The Consortium's strategy}

For the publishers of America one of the most important groups of audience is young people. They most often use materials available in social media. This is in line with current trends in American society. Research and statistics show that one-in-five Americans share their faith online and about the same percentage tune in to religious talk radio, watch religious TV programs or listen to Christian rock music. ${ }^{24}$ The percentage of Americans who said they watched a religious TV program (23\%), listened to religious talk radio $(20 \%)$ or listened to Christian rock music (19\%) is similar to the percentage who share their own faith online. According to the Pew Research Center 40\% of Americans said they shared something about their religious faith "offline, in a real-life setting". American Media on Facebook alone has 90,ooo registered fans; Twitter has over 56,000 ; their YouTube channel has over 10,000 subscribers. ${ }^{26}$ This wide range raises the question about the editorial strategy and hence the so-called „target group" to which primarily this magazine should be addressed.

Tab. Percent of U.S. Adults who Participated in Electronic Religious Activities

\begin{tabular}{|l|c|}
\hline New media: & $\%$ \\
\hline Saw religion shared online & 46 \\
\hline Shared own faith online & 20 \\
\hline & $\%$ \\
\hline Old media: & 23 \\
\hline Watched religious television & 20 \\
\hline Listened to religious talk radio & 19 \\
\hline Listened to Christian rock & \\
\hline
\end{tabular}

Source: American Trends Panel (wave 4); survey conducted May 30 - June 30, 2014; Pew Research Center. ${ }^{27}$

${ }^{24}$ Cf. Pew Research Center, Religion and Electronic Media, https://www.pewforum. org/2014/11/06/religion-and-electronic-media (17.01.2020).

${ }^{25}$ Cf. Pew Research Center, Religion and Electronic Media, https://www.pewforum. org/2014/11/06/religion-and-electronic-media (17.01.2020).

${ }^{26}$ Data received in the Editorial Office of America Media in October 2018 on the basis of ongoing monitoring of social media.

${ }^{27}$ Cf. Pew Research Center, Participation in Electronic and Offline Religious Activities, https:// www.pewforum.org/2014/11/06/religion-and-electronic-media/pf_14-11-06_faithsocial-01-2 (17.01.2020). 
There are two main target groups for America Media. The first one are Catholics seeking a deeper reflection on religion and themes linked with the Church. Therefore, taking into account the needs of this group, the editorial team undertakes various promotional activities. They aimed at facilitating access to the consortium's products for the leaders of movements, groups and ecclesial communities as well as people actively involved in these movements.

The second target group includes those who are not too close to the Church, but want to learn something about Catholicism. They are, therefore, people who are not directly connected with the Church but have a significant influence on public opinion. It could be, for example, media people or politicians. America helps them understand the Catholic mentality and shows them the Church's issues in a simple and comprehensible way. An example may be the presentation of the bishops' position on certain current issues or the summary of the Pope's teaching. Clear transmission of this information, with appropriate commentary, may be for them an important way of understanding a matter which sometimes can be complex and difficult. Statistically, most readers of America Media have a higher education and are involved in the life of their communities and parishes.

Focusing the work of the editors on the above two audiences has a specific impact on the topics and discussion taken up both in the magazine and on social networks. However, the main points of interest are always the current issues of the Church. In the last ten years, one of the most important and difficult topics was the problem of the sexual scandals in US involving the clergy. Recently, events related to this topic have intensified significantly, obviously causing more intensive media interest.

Analysis of this issue and expert commentary has enjoyed great interest, mainly among young people. Based on materials, information and research prepared by America, they conducted a lively discussion in this area, mainly on social media. There were also, of course, voices of people who were not friendly to the Church, who presented positions that were very skeptical about the activities of the Church hierarchy. As the deputy editor-in-chief Maurice Timothy Reidy stressed, despite the often unfavorable atmosphere, the editors tried to present these dramatic facts within a the broader perspective, where the Church is a community of believers. For the members of this community, despite such difficult events, the Church remains something sacred and fundamental in their lives.

In the context of the above analyses, it seems to be extremely important that the materials prepared by America Media are very often cited and used by other 
Catholic media centers in the USA. This confirms the high professionalism of the editorial team as well as the importance and accuracy of the issues discussed.

\section{A Vision for the future - conclusions}

A large number of readers of the America Media consortium websites, and its social networks such as Facebook or YouTube, confirms the growing demand for daily news prepared from the Catholic perspective. However, this is a big financial challenge. Professionally directed new media are expensive to maintain. So what will be the future of the Jesuit consortium? The answer to this question will depend a lot on the financial situation of the consortium and its ability to raise funds for the maintenance of this type of media. The necessary transformations indicate quite unequivocally that America Media will evolve towards an efficiently functioning multimedia platform. In this the sound and television channels play a key role. Video materials are becoming one of the most important challenges at the present time and they are most often followed by Internet users. However, these are activities done mainly by younger audiences. In this context, the important question arises: should the printed version, mainly dedicated to the older audience, continue to be published?

The editors and staff of America Media decided, in recent years, to make significant investments, including in a new headquarters in the center of Manhattan. The layout and graphic design of the printed version of the America magazine was also renewed. The website layout is constantly evolving; the number of proposed podcasts is systematically growing; the community of readers of webpages is constantly increasing. This means that one of the most important issues for the president and editor-in-chief of the consortium - Fr. Matt Malone S.J. - is the constant appeal for new sponsors and donors. Nowadays most of the consortium's expenses are covered by various types of donations.

In spite of extensive marketing activities, it seems necessary to be constantly searching for new, permanent sources of project financing. One of the consequences of that is the intensified promotional policy, as well as the acquisition of well-paid advertising. The target is clear: America Media would like remain a huge mass-media consortium, with a broad vision for the future and with a high position in the ranking of popularity of Catholic media in the United States. 


\section{Bibliography}

About us, The Tablet, https://www.thetablet.co.uk/about (17.01.2020).

America. The Jesuit Review, https://www.americamagazine.org (17.01.2020).

America Media The Jesuit Review. About America Media, https://www.americamagazine. org/about-america-media (17.01.2020).

America Media, a Jesuit Ministry, YouTube Channel, https://www.youtube.com/channel/ UCKrLOIYtxTfjkBy5ho3FSaA (17.01.2020).

EWTN - Eternal Word Television Network, http://www.ewtn.com (17.01.2020).

First Things, https://www.firstthings.com (17.01.2020).

Gęsiak L., Reform of the Vatican media, a difficult search for a new path, "The Person and the Challenges" 7 (2017) 2, pp. 5-22.

Lombardo M. F., Founding Father. John J. Wynne, S.J. and the Inculturation of American Catholicism in the Progressive Era, Leiden-Boston 2017, Brill.

Margolies J., Media Headquarters With Room to Report, Videotape and Worship, “The New York Times" (New York Edition), 18 of July 2018, p. B6.

Martin J., The Examen with Fr. James Martin S.J., https://examen.libsyn.com (17.01.2020).

McLoughlin M., Catholic Magazines and Periodicals, in: M. Glazier, T. J. Shelley (eds.), The Encyclopedia of American Catholic History, Collegeville, Minnesota 1997, The Liturgical Press, p. 275.

Paul VI, Inter Mirifica. Decree on the Media of Social Communication, point 3, http:// www.vatican.va/archive/hist_councils/ii_vatican_council/documents/vat-ii_decree_19631204_inter-mirifica_en.html (17.01.2020).

Pew Research Center, Newspapers Facts Sheet, https://www.journalism.org/fact-sheet/ newspapers (17.01.2020).

Pew Research Center, Participation in Electronic and Offline Religious Activities, https:// www.pewforum.org/2014/11/06/religion-and-electronic-media/pf_14-11-06_faithsocial-01-2 (17.01.2020).

Pew Research Center, Religion and Electronic Media, https://www.pewforum.org/2014/11/06/ religion-and-electronic-media (17.01.2020).

Stahel T. H., America, in: M. Glazier, T. J. Shelley (eds.), The Encyclopedia of American Catholic History, Collegeville, Minnesota 1997, The Liturgical Press, p. 21-22.

The Sacred Heart Messenger. A modern message in a much-loved tradition; https://www. messenger.ie (17.01.2020).

The Tablet, Wikipedia, https://en.wikipedia.org/wiki/The_Tablet (17.01.2020).

Voices, James Martin, S.J. Editor et Large, America, the Jesuit Review, https://www. americamagazine.org/voices/james-martin-sj (17.01.2020). 